\title{
Blood eosinophils as a biomarker of future COPD exacerbation risk: pooled data from 11 clinical trials
}

Dave Singh $^{1 *} \mathbb{D}$, Jadwiga A. Wedzicha², Salman Siddiquil ${ }^{3}$ Alberto de la $\mathrm{Hoz}^{4}$, Wenqiong Xue ${ }^{5}$, Helgo Magnussen ${ }^{6}$, Marc Miravitlles ${ }^{7}$, James D. Chalmers ${ }^{8}$ and Peter M. A. Calverley ${ }^{9}$

\begin{abstract}
Background: Chronic obstructive pulmonary disease (COPD) is characterised by progressive airflow limitation and chronic inflammation. Predicting exacerbations of COPD, which contribute to disease progression, is important to guide preventative treatment and improve outcomes. Blood eosinophils are a biomarker for patient responsiveness to inhaled corticosteroids (ICS); however, their effectiveness as a predictive biomarker for COPD exacerbations is unclear.

Methods: This post hoc analysis pooled data from 11 Boehringer Ingelheim-sponsored Phase III and IV randomised COPD studies with similar methodologies. Exacerbation data were collected from these studies, excluding patients from the ICS withdrawal arm of the WISDOM ${ }^{\circledast}$ study. Patients were grouped according to their baseline blood eosinophil count, baseline ICS use and number of exacerbations in the year prior to each study.

Results: Exacerbation rate data and baseline eosinophil count were available for 22,125 patients; $45.6 \%$ presented with a baseline blood eosinophil count of $\leq 150$ cells/ $\mu \mathrm{L}, 34.3 \%$ with $150-300 \mathrm{cells} / \mu \mathrm{L}$ and $20.1 \%$ with $>300$ cells/ $\mu \mathrm{L}$. The lowest exacerbation rates were observed in patients with $\leq 150 \mathrm{cells} / \mathrm{\mu L}$, with small increases in exacerbation rate observed with increasing eosinophil count. When stratified by exacerbation history, the annual rate of exacerbations for patients with 0 exacerbations in the previous year increased in line with increasing eosinophil counts $(0.38$ for $\leq 150$ cells $/ \mu \mathrm{L}, 0.39$ for $150-300$ cells $/ \mu \mathrm{L}$ and 0.44 for $>300$ cells $/ \mu \mathrm{L}$ respectively). A similar trend was identified for patients with one exacerbation in the previous year, $0.62,0.66$ and 0.67 respectively. For patients with $\geq 2$ exacerbations, exacerbation rates fluctuated between $1.02(\leq 150$ cells $/ \mu \mathrm{L})$ to $1.10(150-300$ cells $/ \mu \mathrm{L})$ and 1.07 (> 300 cells $/ \mu \mathrm{L})$. Higher exacerbation rates were noted in patients treated with ICS at baseline (range 0.75 to 0.82 with increasing eosinophil count) compared with patients not on ICS (range 0.45 to 0.49).

(Continued on next page)
\end{abstract}

\footnotetext{
* Correspondence: DSingh@meu.org.uk

'Medicines Evaluation Unit, University of Manchester, Manchester University NHS Foundation Trust, Manchester, UK

Full list of author information is available at the end of the article
}

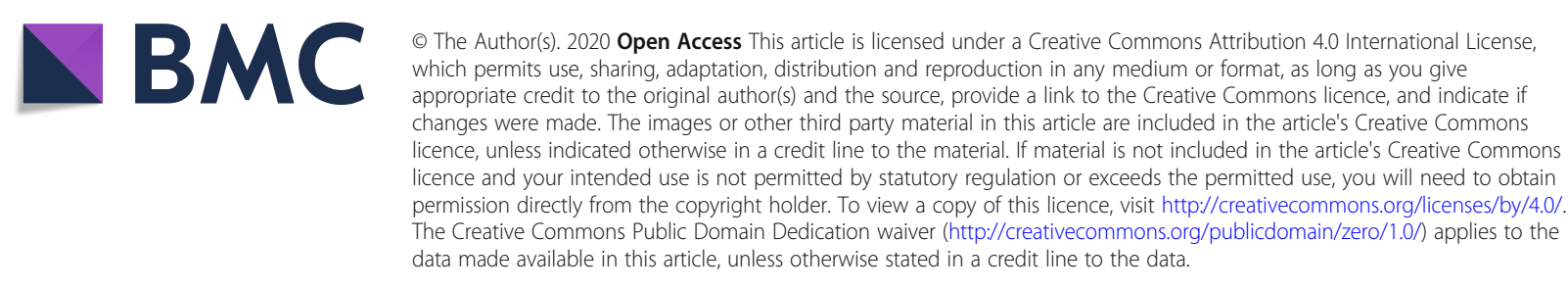


(Continued from previous page)

Conclusion: We found no clinically important relationship between baseline blood eosinophil count and exacerbation rate. Hence, the current analysis does not support the use of blood eosinophils to predict exacerbation risk; however, previous exacerbation history was found to be a more reliable predictor of future exacerbations.

Trial registration: ClinicalTrials.gov Identifiers: NCT00168844, NCT00168831, NCT00387088, NCT00782210, NCT00782509, NCT00793624, NCT00796653, NCT01431274, NCT01431287, NCT02296138 and NCT00975195.

Keywords: Eosinophils, Exacerbations, ICS, Rate ratio, Clinically irrelevant, Randomized controlled trials, Pooled

\section{Plain language summary}

People with chronic obstructive pulmonary disease often start treatment with either a long-acting muscarinic antagonist or a long-acting $\beta_{2}$-agonist. Doctors can prescribe these treatments together (long-acting muscarinic antagonist/long-acting $\beta_{2}$-agonist) if needed. Other medicines called inhaled corticosteroids can be added as required. Measuring the number of eosinophils, a type of white blood cell, in the blood can help to predict which people will benefit most from inhaled corticosteroid treatment.

People with chronic obstructive pulmonary disease sometimes experience a worsening of their symptoms, known as an exacerbation. Eosinophil levels may be useful to predict the risk of exacerbations. We studied the results from 11 clinical trials, involving 22,125 people with chronic obstructive pulmonary disease. We looked at how many exacerbations people had during these trials and whether this was linked to the level of eosinophils in their blood, their previous history of exacerbations, or whether they had been treated with inhaled corticosteroids before.

Overall, we found that a previous history of exacerbations predicted the future rate of exacerbations. We did not find a clear link between the rate of exacerbations and eosinophil levels.

\section{Background}

Characterised by progressive airflow limitation and chronic inflammation, chronic obstructive pulmonary disease (COPD) is a major source of morbidity and mortality that mainly affects individuals above the age of 35 years $[1,2]$. COPD exacerbations, defined as acute worsening of respiratory symptoms requiring a change in treatment [3], are important events that contribute to disease progression. In particular, severe exacerbations (defined as events requiring hospitalisation) are associated with a significantly worse survival and reduced quality of life [3]. The Global Initiative for Chronic Obstructive Lung Disease (GOLD) strategy report recommends that inhaled corticosteroids (ICS), used in combination with long-acting bronchodilator(s), are a useful treatment for patients with a history of exacerbations $[4,5]$. GOLD also supports the use of blood eosinophil counts as a biomarker in clinical practice to predict the likelihood of ICS benefit in terms of preventing future exacerbations [4].

Predicting exacerbations is important for clinicians treating patients with COPD and for designing clinical trials. At present, the strongest predictor of future COPD exacerbations is the past history of moderate and severe exacerbations $[4,6]$. Exacerbation risk is also associated with an increase in symptom severity and worse lung function [7]. Additionally, characteristics such as female sex, older age, lower forced expiratory volume in $1 \mathrm{~s}\left(\mathrm{FEV}_{1}\right)$ and persistent cough have been shown to be predictive of higher exacerbation rates [7, 8]. However, while a number of biomarkers have been studied to predict exacerbations in COPD [3, 9-11], none are currently used in clinical practice.

Randomised controlled trials (RCTs) in COPD patients have shown that blood eosinophil counts predict the response to ICS $[12,13]$. Consequently, blood eosinophil counts have utility in clinical practice to direct ICS use in COPD patients, and as a biomarker in clinical trials to identify subgroups with different responses to antiinflammatory drugs [14]. However, publications investigating the relationship between blood eosinophils and exacerbation risk have produced conflicting results [1519]. Some observational cohort studies have reported that higher eosinophil levels are associated with future COPD exacerbations [15-17], but other studies suggest that there is no relationship $[18,19]$.

RCTs of ICS-containing combination treatments in patients with a history of exacerbations have consistently reported that there is no increase in exacerbation rates at higher blood eosinophil counts in patients allocated to receive ICS treatment, while increased exacerbation rates are observed at higher blood eosinophil counts in patients allocated to receive bronchodilator treatment without ICS [20-22]. This suggests that the use of ICS obscures any relationship between blood eosinophil counts and exacerbation rates.

Another key factor that affects the relationship between eosinophil levels and future exacerbations is the degree of study population enrichment with patients at increased risk of future exacerbations. Previous RCTs of ICS-containing combination treatments demonstrating a 
relationship between blood eosinophil counts and exacerbation rates (in patients randomised to non-ICS treatment) have included patients with a history of exacerbations in the previous year [20]. Furthermore, analysis of the ECLIPSE and COPDgene studies showed that the relationship between exacerbation risk and eosinophil count was clearest in patients with $\geq 2$ exacerbations in the last year [17].

The aim of the present analysis was to further investigate whether blood eosinophil counts predict future rate of exacerbations by pooling data from a large number of clinical trials. These included patients with COPD who experienced exacerbations at different frequencies and of varying severity. Patients were stratified by recognised eosinophil cut-off levels at baseline [23, 24] and the rate of exacerbations was compared between eosinophil subgroups. Exacerbation rates for different eosinophil subgroups were assessed according to exacerbation history and ICS use at baseline.

\section{Methods \\ Study design}

Data from 11 previously published clinical studies were pooled in the current analysis [25-32]. These studies were a collection of Phase III and IV multicentre, double-blindRCTs where patients were treated with tiotropium, olodaterol or tiotropium/olodaterol combination therapy (ClinicalTrials.gov: NCT00168844, NCT00168831, NCT00387088, NCT00782210, NCT00782509, NCT00793624, NCT00796653, NCT01431274, NCT01431287, NCT02296138), as well as the WISDOM ${ }^{\bullet}$ ICS withdrawal study (NCT00975195). The inclusion and exclusion criteria have been described in detail previously [25-32]. Briefly, patients were included if they were aged $\geq 40$ years with a diagnosis of COPD, had a smoking history of $>10$ pack-years, a postbronchodilator $\mathrm{FEV}_{1}$ of $<80 \%$ predicted (or $<60 \%$ ) [26] and a post-bronchodilator $\mathrm{FEV}_{1} /$ forced vital capacity of $<70 \%$. All studies excluded patients with a confirmed diagnosis of asthma. All studies were conducted in accordance with the Declaration of Helsinki and Good Clinical Practice guidelines.

The current analysis focuses on patients with COPD who had documented eosinophil counts at baseline. Studies were included if they recorded exacerbations through the entire study period. The withdrawal arm of the WISDOM trial [31] was excluded from the analysis to avoid including patients with mandated ICS withdrawal. Patients on ICS at baseline continued ICS use during their respective trials.

\section{Statistical analysis}

This post hoc analysis investigated the association between different blood eosinophil count categories
( $\leq 150$ cells $/ \mu \mathrm{L},>150-\leq 300$ cells $/ \mu \mathrm{L}$ and $>300$ cells $/ \mu \mathrm{L})$ and the annual rate of moderate-to-severe exacerbations.

Data from patients across all studies were pooled and exacerbation rate data were analysed according to patients' baseline eosinophil count $(\leq 150$ cells $/ \mu \mathrm{L}$, $>150-\leq 300$ cells $/ \mu \mathrm{L}$ or $>300$ cells $/ \mu \mathrm{L})$, exacerbation history (stratified as either 'infrequent exacerbators' $[\leq 1$ moderate exacerbation and no severe exacerbations in the previous year] or 'frequent exacerbators' [ $\geq 2$ moderate exacerbations or $\geq 1$ severe exacerbation in the previous year]), and ICS use at baseline or according to both ICS use at baseline and exacerbation history. COPD exacerbations were counted from the start to the end of treatment. Patients were followed for the duration of each clinical trial (a minimum of 48 weeks).

Annual rates of exacerbations were assessed using negative binomial models with treatment exposure as offset, adjusted for treatment, study, ICS use at baseline, region, GOLD stage, smoking status, baseline eosinophil count, and number of exacerbations in previous year as covariates.

\section{Results \\ Patient demographics}

From the pooled population, baseline eosinophil data were collected from 22,125 patients who also had exacerbation rate data (Fig. 1). The proportion of patients within each eosinophil subgroup was similar, irrespective of ICS use at baseline or exacerbation history (Fig. $2 \mathrm{a}$ and b). At baseline, the eosinophil count was $\leq 150$ cells $/ \mu \mathrm{L}$ in 10,096 patients $(45.6 \%),>150-\leq 300$ cells $/ \mu \mathrm{L}$ in 7581 patients (34.3\%) and $>300$ cells $/ \mu \mathrm{L}$ in 4448 patients (20.1\%). Median eosinophil count at baseline was 170.0 cells $/ \mu \mathrm{L}$.

Baseline characteristics are shown in Table 1. Mean age, gender split, smoking status, number of pack-years and incidence of moderate-to-severe exacerbations in the previous year were comparable between the three eosinophil subgroups. The majority of patients (74.1\%) were male; $63.2 \%$ were ex-smokers and $36.8 \%$ were current smokers.

\section{Exacerbation rate by eosinophil count and exacerbation history}

In the total patient population, prospective annual exacerbation rates observed during the studies were numerically similar across the three eosinophil subgroups ( $\leq 150$ cells $/ \mu \mathrm{L}, 150-300$ cells $/ \mu \mathrm{L}$ and $>300$ cells $/ \mu \mathrm{L}$; range: $0.62-0.67)$. When compared with patients with a baseline eosinophil count of $\leq 150$ cells $/ \mu \mathrm{L}$, patients in the $>150-\leq 300$ cells $/ \mu \mathrm{L}$ and $>300$ cells $/ \mu \mathrm{L}$ subgroups had exacerbation rate ratios (RRs) of 1.05 (95\% confidence interval $[\mathrm{CI}] 1.00,1.11)$ and 1.09 (95\% CI 1.03, 1.15), respectively (Table 2 ).

In patients with $\leq 1$ exacerbation in the previous year, annual exacerbation rates ranged from 0.51 to 0.57 


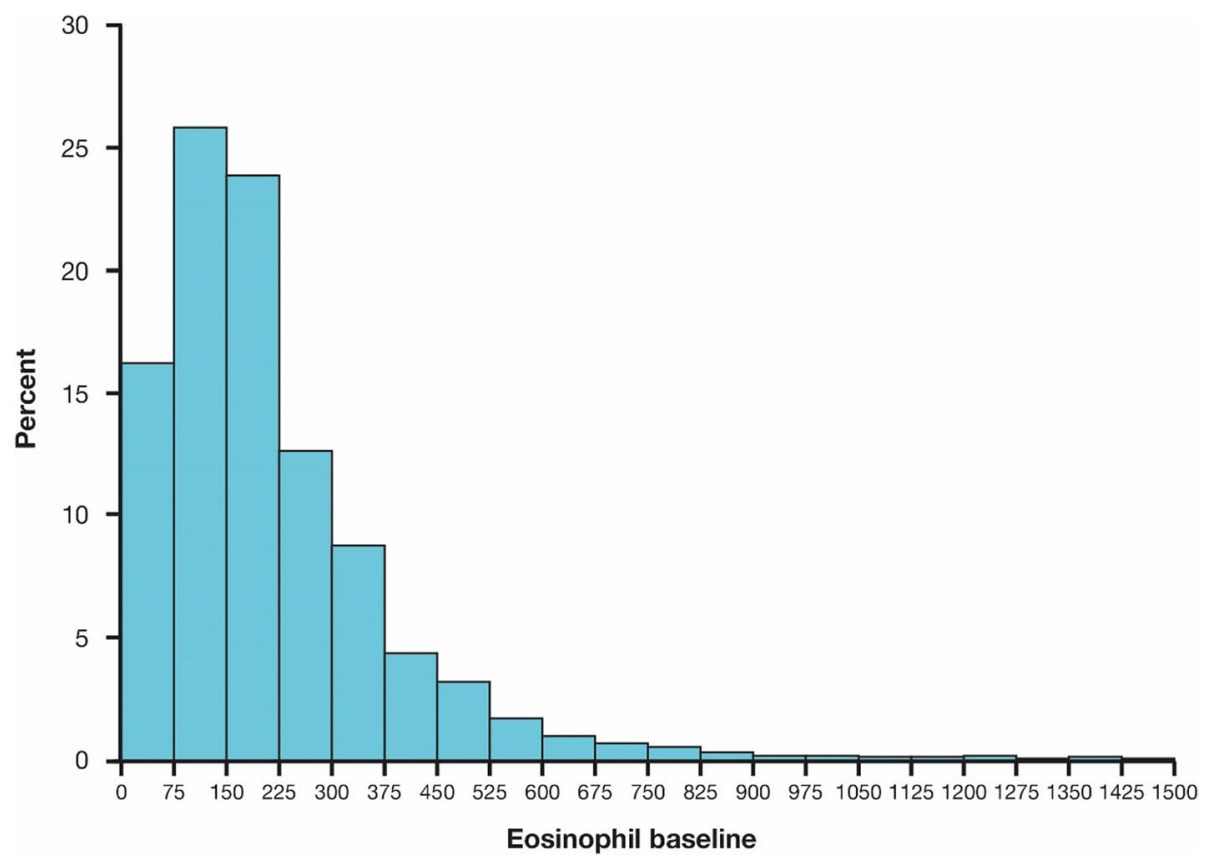

Fig. 1 Baseline blood eosinophil levels in the total population. Baseline blood eosinophil count from 22,125 patients with accompanying exacerbation data

(Table 2). When compared with patients with a baseline eosinophil count of $\leq 150$ cells $/ \mu \mathrm{L}$, patients in the $>150-\leq 300$ cells $/ \mu \mathrm{L}$ and $>300$ cells $/ \mu \mathrm{L}$ subgroups had exacerbation RRs of 1.04 (95\% CI $0.98,1.11)$ and 1.10 (95\% CI 1.03, 1.19), respectively. As shown in Table 2, similar patterns were identified in patients with 0 or 1 exacerbation in the previous year.

In patients with $\geq 2$ exacerbations in the previous year, annual exacerbation rates ranged from 1.02 to 1.10 (Table 2). When compared with patients with a baseline eosinophil count of $\leq 150$ cells $/ \mu \mathrm{L}$, patients in the $>150-\leq 300$ cells $/ \mu \mathrm{L}$ and $>300$ cells $/ \mu \mathrm{L}$ subgroups had RRs of 1.08 (95\% CI $0.99,1.16)$ and 1.04 (95\% CI $0.95,1.15)$, respectively.

\section{Exacerbation rate in patients stratified by ICS use at baseline}

In the pooled analysis, 13,295 patients were receiving ICS at baseline; 8830 patients were not receiving ICS at baseline. Higher annual exacerbation rates were observed in patients receiving ICS at baseline (range 0.75 to 0.82 exacerbations) compared with non-ICS users (range 0.45 to 0.49 ) (Fig. 2b, Table 3).

For patients on ICS at baseline, when compared with the $\leq 150$ cells $/ \mu \mathrm{L}$ group, patients in the $>150-\leq 300$ cells $/ \mu \mathrm{L}$ and $>300$ cells $/ \mu \mathrm{L}$ subgroups had exacerbation RRs of 1.05 (95\% CI 0.99, 1.11) and 1.09 (95\% CI 1.02, 1.17), respectively. For non-ICS patients, when compared with the $\leq 150$ cells $/ \mu \mathrm{L}$ group, patients in the $>150-\leq 300$ cells $/ \mu \mathrm{L}$ and $>300$ cells $/ \mu \mathrm{L}$ subgroups had exacerbation RRs of 1.07 $(95 \%$ CI $0.97,1.17)$ and 1.09 (95\% CI 0.98, 1.21), respectively (Table 3).

\section{Exacerbation rate in patients stratified by exacerbation history before study start and ICS use at baseline}

Table 4 shows the annual exacerbation rates stratified by exacerbation history and ICS use at baseline. For nonICS patients with $\leq 1$ exacerbation in the previous year, patients in the $>150-\leq 300$ cells $/ \mu \mathrm{L}$ and $>300$ cells $/ \mu \mathrm{L}$ subgroups had exacerbation RRs of 1.08 (95\% CI $0.97,1.20)$ and $1.14(95 \%$ CI $1.00,1.29)$, respectively, when compared with the $\leq 150$ cells $/ \mu \mathrm{L}$ group; patients with $\geq 2$ exacerbations in the previous year in the $>150-300$ cells $/ \mu \mathrm{L}$ and $>300$ cells $/ \mu \mathrm{L}$ subgroups had exacerbation RRs of 1.04 (95\% CI $0.88,1.23$ ) and 0.97 (95\% CI 0.79, 1.19), respectively.

In patients treated with ICS at baseline, we identified higher annual exacerbation rates for each of these analyses compared with their non-ICS equivalents (Table 4). For ICS patients with $\leq 1$ exacerbation in the previous year, patients in the $>150-\leq 300$ cells $/ \mu \mathrm{L}$ and $>300$ cells $/ \mu \mathrm{L}$ subgroups had exacerbation RRs of 1.02 (95\% CI $0.95,1.10)$ and 1.10 (95\% CI 1.00, 1.19), respectively, when compared with the $\leq 150$ cells $/ \mu \mathrm{L}$ group; patients with $\geq 2$ exacerbations in the previous year in the $>150-300$ cells $/ \mu \mathrm{L}$ and $>300$ cells $/ \mu \mathrm{L}$ subgroups had exacerbation RRs of 1.09 (95\% CI 1.00, 1.19) and 1.07 (95\% CI 0.96, 1.19), respectively. 
A.

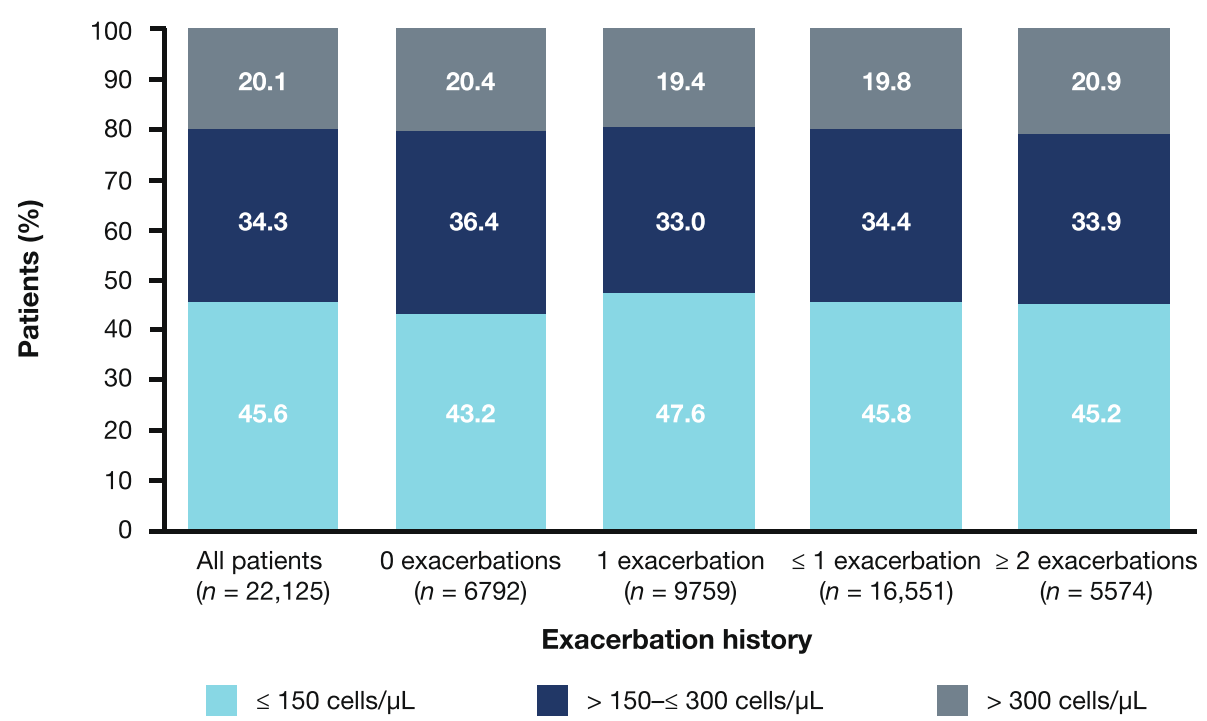

B.

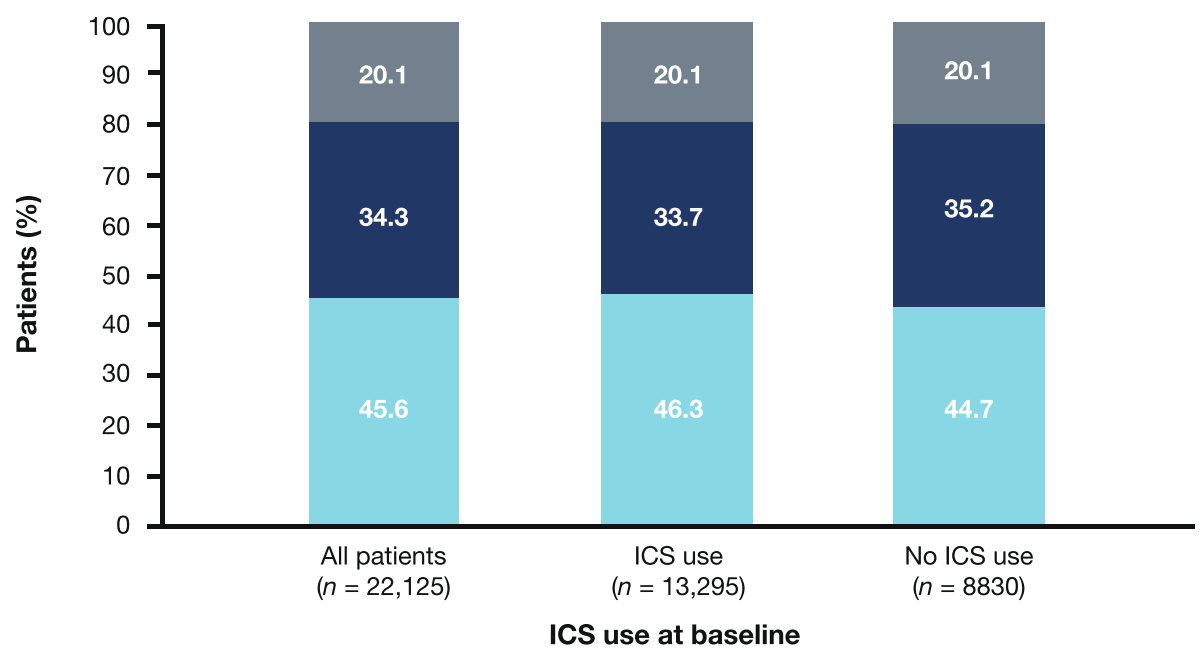

Fig. 2 a Eosinophil count at baseline by exacerbation history. b Eosinophil count at baseline by ICS use. ICS, inhaled corticosteroids

\section{Discussion}

In this analysis, which focuses on the value of blood eosinophil counts as a biomarker for future exacerbations, we did not find a strong association between blood eosinophil counts and annual exacerbation rates during the study period; this was true regardless of exacerbation history or ICS use. There was a pattern across the majority of the subgroups analysed, demonstrating that the lowest exacerbation rates were observed in patients with $\leq 150$ cells $/ \mu \mathrm{L}$. However, the increases in exacerbation rate observed with increasing eosinophil count were small, with RRs between 0.97 and 1.17 .

In line with previous studies, ICS users experienced a higher rate of exacerbations compared with non-ICS users, most likely due to bias by indication, because these patients were receiving ICS as a result of previous exacerbation events [12]. Similarly, patients with a history of $\geq 2$ exacerbations in the previous year also experienced a higher rate of exacerbations (range 1.02-1.10) during the study period than patients with $\leq 1$ exacerbation in the previous year (range $0.51-0.57$ ). This is consistent with previous studies reporting that the best predictor of future exacerbation risk is the patient's exacerbation history [23]. Overall, using exacerbation history or ICS use as stratification factors resulted in an increase in the observed exacerbation rate. We observed over $100 \%$ increase in exacerbation rate in patients with $\geq 2$ exacerbations in the previous year compared with patients with no exacerbations in the previous year. In 
Table 1 Baseline patient characteristics

\begin{tabular}{|c|c|c|c|c|}
\hline Characteristic & $\begin{array}{l}\leq 150 \text { cells/ } / \mu \mathrm{L} \\
(\boldsymbol{n}=10,096)\end{array}$ & $\begin{array}{l}>150-\leq 300 \mathrm{cell} / \mathrm{s} / \mu \mathrm{L} \\
(\boldsymbol{n}=7581)\end{array}$ & $\begin{array}{l}>300 \text { cells/ } / \mu \mathrm{L} \\
(\boldsymbol{n}=4448)\end{array}$ & $\begin{array}{l}\text { Total } \\
(\boldsymbol{N}=22,125)\end{array}$ \\
\hline Male, n (\%) & $7120(70.5)$ & $5694(75.1)$ & $3584(80.6)$ & $16,398(74.1)$ \\
\hline Mean age, years (SD) & $65.3(8.6)$ & $65.0(8.6)$ & $64.6(8.7)$ & $65.1(8.6)$ \\
\hline \multicolumn{5}{|l|}{ Smoking status, n (\%) } \\
\hline Never smoked & $0(0.0)$ & $0(0.0)$ & $1(0.0)$ & $1(0.0)$ \\
\hline Ex-smoker & $6299(62.4)$ & $4788(63.2)$ & $2897(65.1)$ & $13,984(63.2)$ \\
\hline Current smoker & $3797(37.6)$ & $2793(36.8)$ & $1550(34.8)$ & $8140(36.8)$ \\
\hline Smoking history, mean pack-years (SD) & $45.6(26.0)$ & $45.7(25.3)$ & $45.0(25.7)$ & $45.5(25.7)$ \\
\hline \multicolumn{5}{|l|}{ Moderate-to-severe exacerbations in previous year, n (\%) } \\
\hline 0 & $2850(28.2)$ & $2416(31.9)$ & $1347(30.3)$ & $6613(29.9)$ \\
\hline 1 & $4672(46.3)$ & $3229(42.6)$ & $1907(42.9)$ & $9808(44.3)$ \\
\hline 2 & $1565(15.5)$ & $1195(15.8)$ & 709 (15.9) & $3469(15.7)$ \\
\hline 3 & $533(5.3)$ & $385(5.1)$ & $251(5.6)$ & $1169(5.3)$ \\
\hline 4 & $220(2.2)$ & $145(1.9)$ & $107(2.4)$ & $472(2.1)$ \\
\hline$>4$ & $256(2.5)$ & $211(2.8)$ & $127(2.9)$ & $594(2.7)$ \\
\hline \multicolumn{5}{|l|}{ Severe exacerbations in previous year, n (\%) } \\
\hline 0 & $8265(81.9)$ & $6362(83.9)$ & $3683(82.8)$ & $18,310(82.8)$ \\
\hline 1 & $1501(14.9)$ & $970(12.8)$ & $614(13.8)$ & $3085(13.9)$ \\
\hline 2 & $258(2.6)$ & $198(2.6)$ & $115(2.6)$ & $571(2.6)$ \\
\hline 3 & $44(0.4)$ & $31(0.4)$ & $19(0.4)$ & $94(0.4)$ \\
\hline 4 & $19(0.2)$ & $12(0.2)$ & $8(0.2)$ & $39(0.2)$ \\
\hline$>4$ & $9(0.1)$ & $8(0.1)$ & $9(0.2)$ & $26(0.1)$ \\
\hline Mean pre-bronchodilator $\mathrm{FEV}_{1}$ at screening; $\mathrm{L}(\mathrm{SD})$ & $1.15(0.45)$ & $1.18(0.46)$ & $1.16(0.46)$ & $1.16(0.46)$ \\
\hline ICS use at baseline, $\mathrm{n}(\%)$ & $6149(60.9)$ & $4477(59.1)$ & $2669(60.0)$ & $13,295(60.1)$ \\
\hline
\end{tabular}

FEV ${ }_{1}$ Forced expiratory volume in $1 \mathrm{~s}$; ICS Inhaled corticosteroids; SD Standard deviation.

Table 2 Rate ratio of annual exacerbation rates according to exacerbation history by baseline eosinophil count (cells/ $\mu \mathrm{L})$

\begin{tabular}{|c|c|c|c|c|}
\hline & & $\leq 150$ cells $/ \mu \mathrm{L}$ & $>150-\leq 300 \mathrm{cells} / \mu \mathrm{L}$ & $>300$ cells $/ \mu \mathrm{L}$ \\
\hline All & All patients $n=22,125$ & Rate: 0.62 & $\begin{array}{l}\text { Rate: } 0.65 \\
\text { RR: } 1.05 \\
(95 \% \mathrm{Cl} 1.00,1.11)\end{array}$ & $\begin{array}{l}\text { Rate: } 0.67 \\
\text { RR: } 1.09 \\
(95 \% \text { Cl 1.03, 1.15) }\end{array}$ \\
\hline \multirow[t]{4}{*}{ Exacerbation history } & 0 exacerbations $n=6792$ & Rate: 0.38 & $\begin{array}{l}\text { Rate: } 0.39 \\
\text { RR: } 1.01 \\
(95 \% \text { Cl 0.90, 1.12) }\end{array}$ & $\begin{array}{l}\text { Rate: } 0.44 \\
\text { RR: } 1.14 \\
(95 \% \text { Cl 1.00, 1.30) }\end{array}$ \\
\hline & 1 exacerbation $n=9759$ & Rate: 0.62 & $\begin{array}{l}\text { Rate: } 0.66 \\
\text { RR: } 1.07 \\
(95 \% \text { Cl 0.99, 1.15) }\end{array}$ & $\begin{array}{l}\text { Rate: } 0.67 \\
\text { RR: } 1.10 \\
(95 \% \text { Cl 1.01, 1.19) }\end{array}$ \\
\hline & $\leq 1$ exacerbation $n=16,551$ & Rate: 0.51 & $\begin{array}{l}\text { Rate: } 0.53 \\
\text { RR: } 1.04 \\
(95 \% \text { Cl } 0.98,1.11)\end{array}$ & $\begin{array}{l}\text { Rate: } 0.57 \\
\text { RR: } 1.10 \\
(95 \% \text { Cl 1.03, 1.19) }\end{array}$ \\
\hline & $\geq 2$ exacerbations $n=5574$ & Rate: 1.02 & $\begin{array}{l}\text { Rate: } 1.10 \\
\text { RR: } 1.08 \\
\text { (95\% Cl 0.99, 1.16) }\end{array}$ & $\begin{array}{l}\text { Rate: } 1.07 \\
\text { RR: } 1.04 \\
(95 \% \mathrm{Cl} 0.95,1.15)\end{array}$ \\
\hline
\end{tabular}


Table 3 Rate ratio of annual exacerbations according to ICS use by baseline eosinophil count (cells/ $\mu \mathrm{L}$ )

\begin{tabular}{|c|c|c|c|c|}
\hline & & $\leq 150$ cells $/ \mu \mathrm{L}$ & 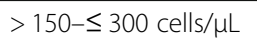 & $>300$ cells $/ \mu \mathrm{L}$ \\
\hline \multirow[t]{2}{*}{ Baseline ICS use } & No $n=8830$ & Rate: 0.45 & $\begin{array}{l}\text { Rate: } 0.48 \\
\text { RR: } 1.07 \\
\text { (95\% Cl } 0.97,1.17 \text { ) }\end{array}$ & $\begin{array}{l}\text { Rate: } 0.49 \\
\text { RR: } 1.09 \\
(95 \% \mathrm{Cl} 0.98,1.21)\end{array}$ \\
\hline & Yes $n=13,295$ & Rate: 0.75 & $\begin{array}{l}\text { Rate: } 0.79 \\
\text { RR: } 1.05 \\
(95 \% \text { Cl } 0.99,1.11)\end{array}$ & $\begin{array}{l}\text { Rate: } 0.82 \\
\text { RR: } 1.09 \\
(95 \% \text { Cl 1.02, 1.17) }\end{array}$ \\
\hline
\end{tabular}

$\mathrm{RR}$ versus $\leq 150$ cells/ $\mu \mathrm{L}$ eosinophil subgroup.

Cl Confidence interval; ICS Inhaled corticosteroids; RR Rate ratio.

contrast, only around a 10\% increase was noted when comparing the lowest eosinophil count with the higher eosinophil counts.

Several analyses of data from RCTs have investigated the relationship between blood eosinophils and ICS use, and have shown that blood eosinophil count correlates with clinical response to ICS with regards to reducing exacerbation rates [20, 33-35]. These study designs include ICS withdrawal for many patients, where treatment differences become apparent at higher blood eosinophil counts; an association between exacerbation rates and blood eosinophil counts can then be more clearly observed in patients not receiving ICS. In the current analysis, none of the 11 individual studies, and by extension the pooled analysis, were designed to study the relationship between blood eosinophils as a predictor of response to ICS in patients experiencing exacerbations, and therefore this topic is beyond the scope of the current manuscript. In the pooled population, which included patients with stable ICS use or non-use, we did not find a strong association between blood eosinophil counts and annual exacerbation rates.

Some cohort studies have also shown an association between blood eosinophil counts and exacerbation risk. Vedel-Krogh et al. found that individuals with a blood eosinophil count above 340 cells/ $\mu \mathrm{L}$ had a higher risk of severe exacerbations compared with patients below this value (odds ratio 1.76; 95\% CI 1.56, 1.99) [15]. In addition, Yun et al. found that patients with blood eosinophil counts $\geq 300$ cells $/ \mu \mathrm{L}$ had an increased risk of exacerbations in the COPDGene study [17]. However, a retrospective study of 992 patients with COPD by Adir et al. found that, among patients who experienced severe exacerbations (72\%) and those that did not (71\%), there was no difference in the proportion of patients with eosinophil counts of $\geq 2 \%(P=0.93)$ [18]. Similarly, a recent population-based study in 57,209 patients with

Table 4 Rate ratio of annual exacerbations combining ICS use and exacerbation history by eosinophil count (cells/ $\mu \mathrm{L}$ )

\begin{tabular}{|c|c|c|c|c|}
\hline & & $\leq 150$ cells $/ \mu \mathrm{L}$ & $>150-\leq 300$ cells $/ \mu \mathrm{L}$ & $>300$ cells $/ \mu \mathrm{L}$ \\
\hline \multirow[t]{8}{*}{ Exacerbation history and ICS use } & 0 exacerbations and no ICS $n=3784$ & Rate: 0.31 & $\begin{array}{l}\text { Rate: } 0.31 \\
\text { RR: } 1.03 \\
\text { (95\% Cl } 0.87,1.21)\end{array}$ & $\begin{array}{l}\text { Rate: } 0.36 \\
\text { RR: } 1.17 \\
(95 \% \text { Cl } 0.97,1.40)\end{array}$ \\
\hline & 0 exacerbations and ICS $n=3008$ & Rate: 0.49 & $\begin{array}{l}\text { Rate: } 0.49 \\
\text { RR: } 1.00 \\
\text { (95\% Cl } 0.86,1.16)\end{array}$ & $\begin{array}{l}\text { Rate: } 0.55 \\
\text { RR: } 1.12 \\
(95 \% \text { Cl } 0.94,1.33)\end{array}$ \\
\hline & 1 exacerbation and no ICS $n=3378$ & Rate: 0.48 & $\begin{array}{l}\text { Rate: } 0.55 \\
\text { RR: } 1.15 \\
(95 \% \text { Cl 1.00, 1.32) }\end{array}$ & $\begin{array}{l}\text { Rate: } 0.52 \\
\text { RR: } 1.09 \\
(95 \% \text { Cl } 0.91,1.29)\end{array}$ \\
\hline & 1 exacerbation and ICS $n=6381$ & Rate: 0.69 & $\begin{array}{l}\text { Rate: } 0.72 \\
\text { RR: } 1.04 \\
(95 \% \text { Cl } 0.95,1.13)\end{array}$ & $\begin{array}{l}\text { Rate: } 0.76 \\
\text { RR: } 1.10 \\
(95 \% \text { Cl 1.00, 1.22) }\end{array}$ \\
\hline & $\leq 1$ exacerbation and no ICS $n=7162$ & Rate: 0.39 & $\begin{array}{l}\text { Rate: } 0.42 \\
\text { RR: } 1.08 \\
\text { (95\% Cl } 0.97,1.20)\end{array}$ & $\begin{array}{l}\text { Rate: } 0.44 \\
\text { RR: } 1.14 \\
(95 \% \text { Cl 1.00, 1.29) }\end{array}$ \\
\hline & $\leq 1$ exacerbation and ICS $n=9389$ & Rate: 0.62 & $\begin{array}{l}\text { Rate: } 0.64 \\
\text { RR: } 1.02 \\
(95 \% \text { Cl } 0.95,1.10)\end{array}$ & $\begin{array}{l}\text { Rate: } 0.68 \\
\text { RR: } 1.10 \\
(95 \% \text { Cl 1.00, 1.19) }\end{array}$ \\
\hline & $\geq 2$ exacerbations and no ICS $n=1668$ & Rate: 0.79 & $\begin{array}{l}\text { Rate: } 0.82 \\
\text { RR: } 1.04 \\
(95 \% \text { Cl } 0.88,1.23)\end{array}$ & $\begin{array}{l}\text { Rate: } 0.76 \\
\text { RR: } 0.97 \\
(95 \% \text { Cl } 0.79,1.19)\end{array}$ \\
\hline & $\geq 2$ exacerbations and ICS $n=3906$ & Rate: 1.13 & $\begin{array}{l}\text { Rate: } 1.24 \\
\text { RR: } 1.09 \\
(95 \% \text { Cl 1.00, 1.19) }\end{array}$ & $\begin{array}{l}\text { Rate: } 1.21 \\
\text { RR: } 1.07 \\
(95 \% \text { Cl } 0.96,1.19)\end{array}$ \\
\hline
\end{tabular}

RR versus $\leq 150$ cells $/ \mu \mathrm{L}$ eosinophil subgroup.

$\mathrm{Cl}$ Confidence interval; ICS Inhaled corticosteroids; RR Rate ratio. 
COPD did not find any relationship between blood eosinophil count and risk of exacerbations [19].

As eosinophil levels are known to vary over time, this may lead to patients fluctuating between different eosinophil categories, despite the patient experiencing only a small absolute change [36, 37]. This may, at least in part, explain why the relationship is difficult to conclude.

When assessing eosinophils in categories, the current study did not show a strong relationship between blood eosinophil counts and risk of future exacerbations. Although there is a paucity of data evaluating blood eosinophil count as a continuous value, Bafadhel et al. [20] modelled eosinophil count as a continuous variable and showed an increase in exacerbation rate in line with increasing eosinophil count in patients not receiving ICS. In clinical practice, eosinophils alone should not be used as a predictor of exacerbation risk, but as a potential biomarker of response to ICS in patients with increased exacerbation risk [20, 33-35].

Other candidate biomarkers have been studied as predictors of increased risk of COPD exacerbations [3, 911], including bone morphogenic protein-3, Cerberus 1 , inhibin B, thrombopoietin, matrix metalloproteinase-10 and a number of interleukin family members [11]. In patients with stable COPD, elevated levels of fibrinogen have been associated with an increased risk of frequent exacerbations [9, 38].

In RCTs, blood eosinophil counts $>300$ cells $/ \mu \mathrm{L}$ are associated with the greatest effect of ICS on exacerbation prevention. In this analysis, $20.1 \%$ had eosinophil counts above this threshold. These results are in line with other studies that suggest that around $25 \%$ of patients have eosinophil counts higher than 300 cells/ $\mu \mathrm{L}[12,19,39]$.

Our analysis has some advantages. Since the pooled studies were all conducted by one pharmaceutical company (Boehringer Ingelheim), the methodologies between these studies are generally compatible. Due to the pooled population, this analysis has a very large sample size and is sufficiently powered to detect even modest changes in exacerbation frequency. However, similar to observational studies, post hoc analyses should be treated with caution as these may be subject to bias. Secondly, the inclusion and exclusion criteria between the studies are mostly generalisable; however, additional factors such as comorbidities may be present in some of the pooled patient population, which were not controlled for and may introduce variability. Thirdly, the pooled studies included a number of active-controlled, or placebo-controlled studies. In COPD, activecontrolled studies compare the drug of interest against a leading comparator in the field. Although more ethical, the results of the active-controlled trials could impact on the overall exacerbation rates. It is important to note that this pooled analysis was not designed to assess a relationship between blood eosinophil count and response to ICS use. The scope of this study was to determine the use of eosinophils as a predictor of exacerbations.

What are the practical implications of our study? For many of the currently studied biomarkers of exacerbation risk, the data are conflicting [40]. Whilst blood eosinophils are recommended as a predictor of likely response to ICS, the results from this pooled analysis indicate that eosinophil levels cannot be confidently used as a predictive marker for rate of future COPD exacerbations, as we were unable to identify a strong relationship between the rate of exacerbations and eosinophil levels. In the absence of a clear biomarker to predict the risk of future exacerbations among patients with COPD, previous history of exacerbations continues to be the strongest predictor of future exacerbation risk [17].

\section{Conclusions}

In this pooled analysis of 22,125 patients with COPD, we did not find a clinically important relationship between baseline blood eosinophil count and exacerbation rate. This analysis, coupled with other studies on this topic [18, 19], indicate that blood eosinophil counts are not a clinically useful predictor of future exacerbation risk.

\section{Abbreviations \\ Cl: Confidence interval; COPD: Chronic obstructive pulmonary disease; $\mathrm{FEV}_{1}$ : Forced expiratory volume in $1 \mathrm{~s}$; GOLD: Global Initiative for Chronic Obstructive Lung Disease; ICS: Inhaled corticosteroids; RCT: Randomised controlled trial; RR: Rate ratio}

\section{Acknowledgements}

Medical writing assistance, in the form of the preparation and revision of the manuscript, was supported financially by Boehringer Ingelheim and provided by Paul Todd, PhD, at MediTech Media, UK under the authors' conceptual direction and based on feedback from the authors. Dave Singh is supported by the National Institute for Health Research (NIHR) Manchester Biomedical Research Centre (BRC).

\section{Authors' contributions}

All authors contributed equally in the development and critical review of the manuscript. The authors read and approved the final manuscript.

\section{Funding}

Support for this project, medical writing support and in the study and collection, analysis, and interpretation of data was provided by Boehringer Ingelheim International $\mathrm{GmBH}$.

\section{Availability of data and materials}

The datasets generated during and/or analysed during the current study are available from the corresponding author on reasonable request.

\section{Ethics approval and consent to participate}

All studies were reviewed and received approval/favourable opinion from the local Institutional Review Board/Independent Ethics Committee and approval by the Competent Authority in each participating European Union member state and other regulatory authorities as required by local laws and regulations. All studies were conducted in accordance with the Declaration of Helsinki and Good Clinical Practice guidelines. 


\section{Competing interests}

DS reports personal fees from Apellis, Cipla, Genentech, Peptinnovate and Skyepharma, and grants and personal fees from AstraZeneca, Boehringer Ingelheim, Chiesi, Glenmark, Merck, Mundipharma, Novartis, Pfizer, Pulmatrix, Teva, Theravance and Verona, outside the submitted work. JAW reports grants from GlaxoSmithKline, Johnson and Johnson, AstraZeneca, Boehringer Ingelheim and Novartis, and other from Novartis, Boehringer Ingelheim, AstraZeneca and GlaxoSmithKline, outside the submitted work. SS reports personal fees and other from Boehringer Ingelheim and Chiesi, and personal fees from GlaxoSmithKline, AstraZeneca, ERT Medical, Owlstone Medical, Mundipharma and Novartis, outside the submitted work. AdlH and WX are both employees of BI. HM reports personal fees from AstraZeneca, Boehringer Ingelheim, Novartis and ndd, during the conduct of the study. MM reports personal fees from Boehringer Ingelheim, Chiesi, GlaxoSmithKline, Menarini, AstraZeneca, Teva, Kamada, Zambon, Grifols, Novartis, Gebro Pharma, CSL Behring, Cipla, Medlmmune, Mereo BioPharma and Sandoz, and grants from GlaxoSmithKline and Grifols, outside the submitted work. JDC reports grants and personal fees from GlaxoSmithKline, Boehringer Ingelheim, Zambon, Insmed, Grifols, Novartis and AstraZeneca, grants from Gilead, and personal fees from Napp, outside the submitted work. PMAC reports grants and personal fees from GlaxoSmithKline, personal fees from AstraZeneca, Boehringer Ingelheim, Recipharm and Zambon, and personal fees and other from Boehringer Ingelheim, outside the submitted work.

\section{Author details \\ ${ }^{1}$ Medicines Evaluation Unit, University of Manchester, Manchester University NHS Foundation Trust, Manchester, UK. ${ }^{2}$ Respiratory Division, National Heart and Lung Institute, Imperial College London, London, UK. ${ }^{3} \mathrm{NIHR}$ Leicester Biomedical Research Centre: Respiratory Theme, and Department of Respiratory Sciences, University of Leicester, Leicester, UK. ${ }^{4}$ Boehringer Ingelheim International $\mathrm{GmbH}$, Ingelheim am Rhein, Germany. ${ }^{5}$ Boehringer Ingelheim Pharmaceuticals, Inc., Ridgefield, CT, USA. ${ }^{6}$ Pulmonary Research Institute at Lung Clinic Grosshansdorf, Grosshansdorf, Germany. ${ }^{7}$ Pneumology Department, Hospital Universitari Vall d'Hebron/Vall d'Hebron Research Institute (VHIR), CIBER de Enfermedades Respiratorias (CIBERES), Barcelona, Spain. ${ }^{8}$ Scottish Centre for Respiratory Research, University of Dundee, Ninewells Hospital and Medical School, Dundee, UK. ${ }^{9} \mathrm{Clinical}$ Science Centre, Institute of Ageing and Chronic Disease, University of Liverpool, Liverpool, UK.}

Received: 29 April 2020 Accepted: 6 August 2020

Published online: 17 September 2020

\section{References}

1. Ford ES. Trends in mortality from COPD among adults in the United States. Chest. 2015;148:962-70.

2. Khachi H, Barnes N, Antoniou S. COPD: clinical features and diagnosis. Clin Pharm. 2010;2:382-9.

3. Viniol C, Vogelmeier CF. Exacerbations of COPD. Eur Respir Rev. 2018;27: 170103.

4. Global Initiative for Chronic Obstructive Lung Disease. Global strategy for the diagnosis, management, and prevention of chronic obstructive pulmonary disease (2020 report). 2019. https:/goldcopd.org/wp-content/uploads/201 9/11/GOLD-2020-REPORT-ver1.0wms.pdf. Accessed June 152020.

5. Singh D, Agusti A, Anzueto A, Barnes PJ, Bourbeau J, Celli BR, et al. Global strategy for the diagnosis, management, and prevention of chronic obstructive lung disease: the GOLD science committee report 2019. Eur Respir J. 2019;53:1900164.

6. Calverley PM, Tetzlaff K, Dusser D, Wise RA, Mueller A, Metzdorf N, et al. Determinants of exacerbation risk in patients with COPD in the TIOSPIR study. Int J Chron Obstruct Pulmon Dis. 2017;12:3391-405.

7. Hurst JR, Vestbo J, Anzueto A, Locantore N, Mullerova H, Tal-Singer R, et al. Susceptibility to exacerbation in chronic obstructive pulmonary disease. N Engl J Med. 2010;363:1128-38.

8. Husebo GR, Bakke PS, Aanerud M, Hardie JA, Ueland T, Gronseth R, et al. Predictors of exacerbations in chronic obstructive pulmonary disease-results from the Bergen COPD cohort study. PLoS One. 2014;9:e109721.

9. Pais R. Biomarkers for predicting COPD exacerbations. Thorax. 2014;69:767.

10. Chen Y-WR, Leung JM, Sin DD. A systematic review of diagnostic biomarkers of COPD exacerbation. PLoS One. 2016;11:e0158843.
11. Chen H, Wang Y, Bai C, Wang X. Alterations of plasma inflammatory biomarkers in the healthy and chronic obstructive pulmonary disease patients with or without acute exacerbation. J Proteome. 2012;75:2835-43.

12. Vestbo J, Vogelmeier CF, Small M, Siddall J, Fogel R, Kostikas K. Inhaled corticosteroid use by exacerbations and eosinophils: a real-world COPD population. Int J Chron Obstruct Pulmon Dis. 2019;14:853-61.

13. Papi A, Kostikas K, Wedzicha JA, Vogelmeier CF, Roche N, Shen S, et al. Dual bronchodilation response by exacerbation history and eosinophilia in the FLAME study. Am J Respir Crit Care Med. 2018;197:1223-6.

14. Singh $D$, Bafadhel $M$, Brightling $C E$, Sciurba FC, Curtis JL, Martinez FJ, et al. Blood eosinophil counts in clinical trials for chronic obstructive pulmonary disease. Am J Respir Crit Care Med. 2020;202(5):660-71. https://doi.org/10. 1164/rccm.201912-2384PP.

15. Vedel-Krogh S, Nielsen SF, Lange P, Vestbo J, Nordestgaard BG. Blood eosinophils and exacerbations in chronic obstructive pulmonary disease. The Copenhagen general population study. Am J Respir Crit Care Med. 2016;193:965-74.

16. Kerkhof M, Sonnappa S, Postma DS, Brusselle G, Agusti A, Anzueto A, et al. Blood eosinophil count and exacerbation risk in patients with COPD. Eur Respir J. 2017;50:1700761.

17. Yun JH, Lamb A, Chase R, Singh D, Parker MM, Saferali A, et al. Blood eosinophil count thresholds and exacerbations in patients with chronic obstructive pulmonary disease. J Allergy Clin Immunol. 2018;141:2037-47 e10.

18. Adir Y, Hakrush O, Shteinberg M, Schneer S, Agusti A. Circulating eosinophil levels do not predict severe exacerbations in COPD: a retrospective study. ERJ Open Res. 2018;4:00022-2018.

19. Miravitlles M, Monteagudo M, Solntseva I, Alcázar B. Blood eosinophil counts and their variability and risk of exacerbations in COPD: a populationbased study. Arch Bronconeumol. 2020:50300-2896(19)30623-4.

20. Bafadhel M, Peterson S, De Blas MA, Calverley PM, Rennard SI, Richter K, et al. Predictors of exacerbation risk and response to budesonide in patients with chronic obstructive pulmonary disease: a post-hoc analysis of three randomised trials. Lancet Respir Med. 2018;6:117-26.

21. Pascoe S, Barnes N, Brusselle G, Compton C, Criner GJ, Dransfield MT, et al. Blood eosinophils and treatment response with triple and dual combination therapy in chronic obstructive pulmonary disease: analysis of the IMPACT trial. Lancet Respir Med. 2019;7:745-56.

22. Singh D. Predicting corticosteroid response in chronic obstructive pulmonary disease. Blood eosinophils gain momentum. Am J Respir Crit Care Med. 2017;196:1098-100.

23. Brusselle G, Pavord ID, Landis S, Pascoe S, Lettis S, Morjaria N, et al. Blood eosinophil levels as a biomarker in COPD. Respir Med. 2018;138:21-31.

24. Chapman KR, Hurst JR, Frent S-M, Larbig M, Fogel R, Guerin T, et al. Longterm triple therapy de-escalation to indacaterol/glycopyrronium in patients with chronic obstructive pulmonary disease (SUNSET): a randomized, double-blind, triple-dummy clinical trial. Am J Respir Crit Care Med. 2018; 198:329-39.

25. Bateman E, Singh D, Smith D, Disse B, Towse L, Massey D, et al. Efficacy and safety of tiotropium Respimat SMI in COPD in two 1-year randomized studies. Int J Chron Obstruct Pulmon Dis. 2010;5:197-208.

26. Tang Y, Massey D, Zhong NS. Evaluation of the efficacy and safety of tiotropium bromide (5 microg) inhaled via Respimat in Chinese patients with chronic obstructive pulmonary disease. Chin Med J (Engl). 2013;126:3603-7.

27. Ferguson GT, Feldman GJ, Hofbauer P, Hamilton A, Allen L, Korducki L, et al. Efficacy and safety of olodaterol once daily delivered via Respimat ${ }^{\oplus}$ in patients with GOLD 2-4 COPD: results from two replicate 48-week studies. Int J Chron Obstruct Pulmon Dis. 2014;9:629-45.

28. Koch A, Pizzichini E, Hamilton A, Hart L, Korducki L, De Salvo MC, et al. Lung function efficacy and symptomatic benefit of olodaterol once daily delivered via Respimat ${ }^{\oplus}$ versus placebo and formoterol twice daily in patients with GOLD 2-4 COPD: results from two replicate 48-week studies. Int J Chron Obstruct Pulmon Dis. 2014;9:697-714.

29. Buhl R, Maltais F, Abrahams R, Bjermer L, Derom E, Ferguson G, et al. Tiotropium and olodaterol fixed-dose combination versus monocomponents in COPD (GOLD 2-4). Eur Respir J. 2015;45:969-79.

30. Calverley PMA, Anzueto AR, Carter K, Gronke L, Hallmann C, Jenkins C, et al. Tiotropium and olodaterol in the prevention of chronic obstructive pulmonary disease exacerbations (DYNAGITO): a doubleblind, randomised, parallel-group, active-controlled trial. Lancet Respir Med. 2018;6:337-44. 
31. Magnussen $H$, Disse B, Rodriguez-Roisin R, Kirsten A, Watz H, Tetzlaff $K$, et al. Withdrawal of inhaled glucocorticoids and exacerbations of COPD. N Engl J Med. 2014;371:1285-94.

32. Bateman ED, Tashkin D, Siafakas N, Dahl R, Towse L, Massey D, et al. A oneyear trial of tiotropium Respimat plus usual therapy in COPD patients. Respir Med. 2010;104:1460-72.

33. Siddiqui SH, Guasconi A, Vestbo J, Jones P, Agusti A, Paggiaro P, et al. Blood eosinophils: a biomarker of response to extrafine beclomethasone/ formoterol in chronic obstructive pulmonary disease. Am J Respir Crit Care Med. 2015;192:523-5.

34. Pascoe S, Locantore N, Dransfield MT, Barnes NC, Pavord ID. Blood eosinophil counts, exacerbations, and response to the addition of inhaled fluticasone furoate to vilanterol in patients with chronic obstructive pulmonary disease: a secondary analysis of data from two parallel randomised controlled trials. Lancet Respir Med. 2015:3:435-42.

35. Watz H, Tetzlaff K, Wouters EF, Kirsten A, Magnussen H, Rodriguez-Roisin R, et al. Blood eosinophil count and exacerbations in severe chronic obstructive pulmonary disease after withdrawal of inhaled corticosteroids: a post-hoc analysis of the WISDOM trial. Lancet Respir Med. 2016;4:390-8.

36. Southworth $T$, Beech $G$, Foden P, Kolsum U, Singh D. The reproducibility of COPD blood eosinophil counts. Eur Respir J. 2018;52:1800427.

37. Singh D, Kolsum U, Brightling CE, Locantore N, Agusti A, Tal-Singer R. ECLI PSE investigators. Eosinophilic inflammation in COPD: prevalence and clinical characteristics. Eur Respir J. 2014:44:1697-700.

38. Thomsen M, Ingebrigtsen TS, Marott JL, Dahl M, Lange P, Vestbo J, et al. Inflammatory biomarkers and exacerbations in chronic obstructive pulmonary disease. JAMA. 2013;309:2353-61.

39. Calverley PM, Tetzlaff K, Vogelmeier C, Fabbri LM, Magnussen $H$, Wouters EF, et al. Eosinophilia, frequent exacerbations, and steroid response in chronic obstructive pulmonary disease. Am J Respir Crit Care Med. 2017;196:1219-21.

40. Eagan TM, Ueland T, Wagner PD, Hardie JA, Mollnes TE, Damas JK, et al. Systemic inflammatory markers in COPD: results from the Bergen COPD cohort study. Eur Respir J. 2010;35:540-8.

\section{Publisher's Note}

Springer Nature remains neutral with regard to jurisdictional claims in published maps and institutional affiliations.

Ready to submit your research? Choose BMC and benefit from:

- fast, convenient online submission

- thorough peer review by experienced researchers in your field

- rapid publication on acceptance

- support for research data, including large and complex data types

- gold Open Access which fosters wider collaboration and increased citations

- maximum visibility for your research: over $100 \mathrm{M}$ website views per year

At $\mathrm{BMC}$, research is always in progress.

Learn more biomedcentral.com/submissions 